\title{
Kaizen Toward Learning, Transformation, and High-Quality Growth: Insights from Outstanding Experiences
}

\author{
Akio Hosono
}

Kaizen is a Japanese word that literally means "improvement" but is also commonly referred to as "continuous improvement." Now a well-known concept worldwide, it normally refers to the Japanese approach toward improving quality and productivity. What distinguishes Kaizen from other approaches is that these goals are attained through its process-one in which learning and inclusiveness are essential. The sustainable development goals (SDGs) call on member states to promote sustained, inclusive, and sustainable economic growth and decent work for all. Kaizen can contribute to achieving the kind of growth characterized by these attributes. In this chapter, I begin by providing an analytical perspective and discussion of key issues related to Kaizen (Sect. 1). Based on this discussion, I then review the goals, tools/methods, and process of Kaizen (Sect. 2). In Sect. 3, I discuss the relationship between Kaizen and the targets of the SDGs as well as learning, transformation, and quality of growth. In Sect. 4, I analyze outstanding experiences of some countries that have

A. Hosono $(\square)$

JICA Research Institute, Tokyo, Japan

e-mail: Hosono.Akio@jica.go.jp

(C) The Author(s) 2020

A. Hosono et al. (eds.), Workers, Managers, Productivity, https://doi.org/10.1007/978-981-15-0364-1_3 
introduced Kaizen or similar approaches to gather insights on the relationship. Finally, I provide some concluding remarks. ${ }^{1}$

\section{Analytical Perspective and Key Issues}

In recent policy debates on growth and development, increasing attention is being paid to the "quality" of economic growth. ${ }^{2}$ In Asia and the Pacific region, APEC leaders at Yokohama in 2010 agreed on the "APEC Growth Strategy." This strategy stresses that "the quality of growth" needs to be improved so that it will be more balanced, inclusive, sustainable, innovative, and secure. In 2015, the Japanese government announced the Charter of Development Cooperation. It stated that one of the most important challenges of development is “ 'quality growth' and poverty eradication through such growth" while also stressing inclusiveness, sustainability, and resilience (Government of Japan, Cabinet Office 2015, 5-6). In that same year, the United Nations passed a resolution adopting "Transforming Our World: The 2030 Agenda for Sustainable Development" as its post2015 development agenda. This outcome document sets out "The Sustainable Development Goals (SDGs)" and targets as integrated and indivisible, global in nature, and universally applicable (UNGA 2015). Among the 17 Global Goals and 169 targets, Goal 8 calls on member states to promote sustained, inclusive, and sustainable economic growth, full and productive employment, and decent work for all, while Goal 9 calls on governments to "build resilient infrastructure, promote inclusive and sustainable industrialization and foster innovation." As such, the SDGs-in particular Goals 8 and 9-largely overlap with the abovementioned attributes of "quality growth."

Together with quality of growth, another feature of the SDGs is the importance placed on transformation. The above-cited United Nations 2030 Agenda declares that "We are determined to take the bold and transformative steps which are urgently needed to shift the world on to a sustainable and resilient path" (UNGA 2015,2). Transformation-led growth is distinct from, for example, commodity price hike-led growth. Transformation-led growth could be high-quality growth and could generate further transformation. This implies that a virtuous circle of transformation and high-quality growth could take place. The ADB report on transformation $(2013,5)$ argues that, when structural transformation creates a virtuous circle, it leads to high growth and higher income per capita, and these induce further changes in the structure of the economy. 
Regarding ways that such transformation can be achieved, there seems to be a growing consensus in the academic literature that structural transformation is closely related to changes of endowments or assets, changes in comparative advantage, and, finally, increasing innovation and technological progress. As Noman and Stiglitz emphasize, "the essence of development is dynamic. What matters, for instance, is not comparative advantage as of today, but dynamic comparative advantage" (Noman and Stiglitz 2012, 7). Lin, likewise, discusses "changing comparative advantage," arguing that "the more effective route for their learning and development is to exploit the advantages of backwardness and upgrade and diversify into new industries according to the changing comparative advantages determined by the changes in their endowment structure" (Lin 2012, 73).

Accordingly, endowments are extremely important for transformation based on changing or dynamic comparative advantage. In this regard, recent studies identified critical endowments for transformation. Drawing from many previous studies, Stiglitz and Greenwald (2014) present a systematic and holistic analysis of what constitutes a learning society, concluding that "the most important 'endowment' from our perspective, is a society's learning capacities." They further state that a country's policies have to be shaped to take advantage of its comparative advantage in knowledge and learning abilities, including its ability to learn and to learn to learn, in relation to its competitors and to help develop those capacities and capabilities further (26). Noman and Stiglitz (2017) reaffirm the importance of learning capacity, together with institutions: "Perhaps the most important 'endowment' of a country was assets that were not mobile-institutions and learning capacities that were embedded in local institutions. It was these that countries needed to take into account as they struggled to shape their long-term (dynamic) comparative advantage" (13).

Stiglitz and Greenwald also emphasize the relationship between learning capacity and inclusive growth. Inclusive growth has two interrelated aspects: all people participate in inclusive growth and, at the same time, benefit from it. But, from a "learning society" perspective, inclusive growth goes far beyond the above-mentioned aspects and has an intrinsic relationship with innovative growth. Growth can be really inclusive-and, at the same time, innovative-when such growth takes full advantage of the talents of all. Stiglitz and Greenwald (2014) state that "our argument for why inclusive growth is so important goes beyond the standard one 
that it is a waste of a country's most valuable resource, its human talent, to fail to ensure that everyone lives up to his or her abilities" (468). They suggest that policies to promote more inclusiveness may promote more learning (381).

\subsection{Research Question and Structure of This Chapter}

The overarching research question of this chapter is: what benefits can we expect from Kaizen and related approaches in terms of learning, transformation, and quality growth? The next sections discuss goals, tools/methods, and process of Kaizen, and their relationship to learning, transformation, and quality of growth. In order to obtain deeper insights into these relationships, we examine the experiences of several countries where Kaizen and related approaches/systems have been introduced.

\section{Goals, Tools/Methods, and Process of Kaizen}

\subsection{Goals of Kaizen and Process to Achieve Them}

Much of the literature on Kaizen concurs that the utmost goal of Kaizen is the improvement of quality and productivity. For example, JICA's brochure, "Kaizen as a 'Japan brand ODA,'" states that Kaizen is Japan's approach toward improved quality and productivity (JICA 2016). However, it should be emphasized that Kaizen is distinctive in its approach to improving quality and productivity and that there are other approaches to improving productivity. For example, employers typically turn to monetary incentives: performance pay, bonuses, or the threat of dismissal (World Bank 2015, ch. 7). Nevertheless, any increase in productivity resulting from these approaches over a short period is normally not accompanied by learning. Where Kaizen differs from these approaches is in its process for achieving better quality and productivity through its distinctive focus on inclusive and participatory learning. Stiglitz and Greenwald (2014) contend that "if it is true that productivity is the result of learning and that productivity increases (learning) are endogenous, then a focal point of policy ought to be increasing learning within the economy" (5-6). I will discuss the learning aspects of Kaizen in the next section. 


\subsection{Kaizen Tools/Methods}

Many Kaizen tools and methods have been developed over more than half a century. They are essential for the process of achieving the goals of Kaizen. For example, the Asian Productivity Organization (APO) states that "Kaizen approaches employ various tools including 5S, quality control circles, total quality control, total preventive maintenance, just-intime inventory, standard work, and automation, among others. These have all been useful in improving the three productivity dimensions of cost, quality, and speed. For example, the core concept of Kaizen is to eliminate muri (overloading), muda (waste), and mura (inconsistency) from the worksite through efficient utilization of labor, materials, and equipment" (APO 2015, 10).

Among typical Kaizen tools and methods, $5 \mathrm{~S}$ and Quality Control Circles (QCC) are well known. 5S represents "Sort, Set in order (or Systematic arrangement), Shine (or Sweep), Standardize, Sustain," which corresponds to five simple actions that can be taken to obtain discernible results of Kaizen in a short period of time (JICA 2016; italics added by author). "Sort" refers to sorting necessary items from un-necessary items and tidying up any items that aren't needed. "Systematic arrangement" indicates the need to place items in their set positions so that they can be used immediately when needed (Kikuchi 2009). These activities are practiced with simple methods such as the tag method, color display, visual controls, and dividing lines. As such, $5 \mathrm{~S}$ is an easy activity to start with and enables the participation of all.

Quality Control Circles (commonly called QC circles) are voluntary small-scale groups that solve onsite problems through teamwork (JICA 2016). This Japanese way of QCC was gradually consolidated when it was applied at the factory floor level. In QC activities, participants frequently collect data and identify the causes of defective products and possibilities for improving products or production methods based on information collected. The basic tools used to read various kinds of information from data are referred to as the seven tools of QC, which include Pareto diagrams, check sheets, histograms, scatter diagrams, control drawings, graphs, and cause and effect diagrams (Kikuchi 2009, 45).

Many other tools, especially those of easy application including "layout planning" based on transfer distance analysis and process proximity analysis, improvement of work/human hours balance, shortening of setup times, are implemented during the Kaizen process (Kikuchi 2009). 


\section{Kaizen, Learning, and Quality of Growth}

\subsection{Kaizen as a Participatory and Inclusive Approach}

The APO explains that the inclusiveness of the Kaizen process is centered around improvement efforts through the participation of all. Its "Handbook of Productivity" asserts that "Kaizen means improvement and encompasses the concept of never-ending efforts to improve by all of the people working in an organization. Problem-solving in the Kaizen approach is cross-functional, systematic, and collaborative. It is a strategy that puts every member of the organization, from top management down, continuously on the watch for improvement options" (APO 2015, 9-10). JICA (2016) succinctly states that "KAIZEN is an incremental effort starting from small steps involving all individuals from top managers to those working on the factory floor. However, commitment from the top management is essential."

\subsection{Kaizen and Learning}

The next question concerns how Kaizen can facilitate learning. To answer this, we need to discuss determinants of learning and how Kaizen is related to them. Stiglitz and Greenwald $(2014,56-57)$ identified the following major determinants of learning: (1) learning capabilities; (2) access to knowledge; (3) catalysts for learning; (4) creating a creative mindset or developing the right cognitive frames; (5) contacts-people with whom one interacts-who can catalyze learning, help create the right cognitive frame, and provide crucial inputs into the learning process; and (6) the context of learning. They further mention that "Just as knowledge itself is endogenous, so is the ability to learn. Some economic activities (conducted in certain ways) not only facilitate learning, they may facilitate learning to learn" (50; italics in original).

Several studies on capacity development also refer to the two types of capacity. Capacity embodies not only specific technical elements, such as specific health care or road construction skills, but also so-called core capacities (Hosono et al. 2011, 180). They include generic and crosscutting competencies and the ability to commit and engage, to identify needs and key issues, to plan, budget, execute, and monitor actions, and, most importantly, to acquire knowledge and skills (UNDP 1998; ECDPM 2008; JICA 2006, 2008). 
Kaizen tools/methodology and process bear a close relationship to the determinants of learning and, in particular, learning to learn. As JICA (2016) emphasizes, the Kaizen process (1) changes the mindsets of managers and workers; 2 ) fosters personnel who can think and act themselves; and (3) solves problems as a team, thereby promoting teamwork. This learning process is most visible in the activities of QC Circles (QCC). According to Ishikawa (1990), father of QCC, ${ }^{4}$ "The basic philosophy of QC circle activities carried out as part of companywide quality control activities is (1) to contribute to the improvement and development of the corporate culture, (2) to create cheerful workplaces that make life worthwhile and where humanity is respected, and (3) to exercise people's capabilities and bring out their limitless potential" (78-79; italics added). Here we find exactly what Stiglitz and Greenwald (2014) emphasized regarding the real meaning of inclusive growth, which is intrinsically innovative growth in the sense that "it is a waste of a country's most valuable resource, its human talent, to fail to ensure that everyone lives up to his or her abilities" (468; italics added).

\subsection{Kaizen, TQC/TQM, Organizational Learning, and Learning Firms}

The Japanese way of QC was gradually scaled up from the factory floor level to the whole company. At the same time, all company employees, including managers, engineers, supervisors, office workers, as well as frontline factory workers participated in QC. This holistic approach, developed in Japan, is referred to as the Japanese type of company-wide quality control (CWQC) or total quality control (TQC). The TQC practiced by Japanese companies evolved, with much refinement, to total quality management (TQM) in the late $1980 \mathrm{~s}^{5}$ As such, TQM is a kind of management system and strategy based on CWQC or TQC, and is widely promoted in the 1980s in Japan. ${ }^{6}$ However, the term TQM was first used in the United States when US companies learned TQC from Japan. In 1996, JUCE decided to substitute the TQC by TQM (Fujimoto 2003, 302). "The Handbook for TQM and QCC," edited by the Development Bank of Japan and the Japan Economic Research Institute, notes that "[TQM] includes a number of management practices, philosophies and methods to improve the way an organization does business, makes its products, and interacts with its employees and customers. Kaizen is one of those philosophies" (DBJ and JERI 2003, vii). 
The Toyota Production System (commonly called TPS) can be considered one of the most systematic and advanced Japanese TQC or TQM systems. As Liker (2004), the author of Toyota Way, ${ }^{7}$ stated, "Toyota invented 'lean production'-also known as 'the Toyota Production System' or TPS - which has triggered a global transformation in virtually every industry to Toyota's manufacturing and supply chain philosophy and methods over the last decade" (4). He further states that "TPS is often known as 'lean' or 'lean production', since these were the terms made popular in two best-selling books: The Machine That Changed the World: The Story of Lean Production (Womack et al. 1990) and Lean Thinking (Womack and Jones 1996). These authors make it clear that the foundation of their research on lean production is TPS and its development by Toyota" (Womack et al. 1990, 3-4; Liker 2004, 15).

In the 1990s, through the work conducted on the International Motor Vehicle Program (IMVP) by The Massachusetts Institute of Technology (MIT) and the above-mentioned bestsellers based on its research, the concept of "lean production" was discovered by the world manufacturing community (Liker 2004, 25). The study authors applied this term to what Toyota had learned a decade earlier: "through focusing on speed within its supply chain: shortening lead time by eliminating waste in each step of a process leads to best quality and lower cost, while improving safety and morale" (Liker 2004, 25; italics in original). The idea of shortening leadtime by eliminating waste in each step is related to the concept of just-intime (JIT). "Simply put, JIT delivers the right items at the right time in the right amounts. The power of JIT is that it allows you to be responsive to the day-by-day shifts in customer demand, which was exactly what Toyota needed all along" (Liker 2004, 23).

Liker (2004) highlighted the importance of learning in TPS: "I believe Toyota has raised continuous improvement and employee involvement to a unique level, creating one of the few examples of a genuine learning enterprise in human history - not a small accomplishment" (xv; italics added). He further states: "The highest level of the Toyota Way is organizational learning. Identifying the root causes of problems and preventing them from occurring is the focus of Toyota's continuous learning system" (xvi). This concept of a learning enterprise is similar to the exploration by Stiglitz and Greenwald of the "learning firm" which, together with a learning macro-environment, constitutes critical aspects of learning architecture $(2014,88)$. The importance of the learning firm is emphasized by them because "so much learning occurs within organizations and because so much knowledge resides within firms." 


\subsection{Kaizen and Sustainable Growth}

A core method of Kaizen is to eliminate muri, muda, and mura from the worksite through efficient utilization of labor, materials, and equipment. As such, the concept of environmental sustainability is intrinsically incorporated into Kaizen, TQM and related approaches from the beginning. Furthermore, these approaches have focused more on activities for energy conservation and measures for resource management in the post-oil crises period. In this regard, the "Total Energy Management Handbook" prepared in 2005 by the Energy Conservation Center Thailand (ECCT) and Energy Conservation Center Japan (ECCJ) puts stress on such items as motivation techniques, energy conservation attitudes, and small group activities (SGA) including TQM, all contributing to energy conservation through the participation of all the people working together (ECCT and ECCJ 2005, 4). The Asian Energy Efficiency and Conservation Collaboration Center (AEEC) was established by ECCJ in 2007. There have also been many initiatives to mainstream environmental sustainability in Kaizen, TQM, and so forth. For example, APO started to promote "green productivity" focusing explicitly on environmental improvement.

\subsection{Kaizen and Secure Growth}

The APEC growth strategy included "secure growth" as an attribute of the quality of growth and stated: "We seek to protect the region's citizen's economic and physical well-being and to provide the secure environment necessary for economic activity." Secure working conditions are explicitly and implicitly included among basic aims of 5S, elimination of muri and mura, as well as related approaches. As such, Kaizen aims to upgrade quality and productivity, improving the security and safety of workers at the same time.

\section{Insights From OUtstanding Experiences}

\subsection{Experiences in Japan}

Much of the literature related to Kaizen acknowledges its significant contributions to industrial development in Japan. For example, APO (2015) emphasizes that "Kaizen is known as the single most important concept in Japanese management and it has been a key to the competitive success of 
Japanese manufacturing industries." JICA (2016) notes that Kaizen is "the driving force of Japan's rapid growth." DBJ and JERI (2003) state that "The success of Japanese business in Canada, Latin America, and the United States as well as in Europe is attributable to TQM, a concept now widely practiced throughout Asia."

Only a few Japanese companies, such as Toyota, were aware of the importance of the US-derived statistical control of quality before Dr. William Edwards Deming came to Japan in 1947 and gave a series of lectures on the statistical process control of production and quality. Accordingly, the first step for many Japanese companies was the introduction of the statistical quality control (SQC) approach. The Japanese way of QC was gradually consolidated when it was applied at the factory floor level with the introduction of, among other things, Kaizen and QCC. The number of QCC could be considered as a kind of proxy indicator of the dissemination of Kaizen. The number of QCCs registered at the Union of Japanese Scientists and Engineers (JUSE) increased from 50,000 in the mid-1970s to 420,000 in 2001 . The number of participants of QCCs increased from 500,000 to 3,200,000 during the same period (DBJ and JERI 2003, 59). As this shows, the large-scale dissemination of Kaizen has taken place since 1970s. It should be also noted that Kaizen - and in particular QCC—-has been introduced not only into the manufacturing sector but also in various other sectors, such as the construction sector (since 1975), finance and insurance sectors (since 1981), and health care sector (hospitals) (since 1982) (DBJ and JERI 2003, 59).

According to a recent study on productivity gaps for Japanese and US industries by Jorgenson et al. $(2015,21-26)$, the total factor productivity (TFP) gaps of Japan compared to the United States were very large in both the manufacturing and non-manufacturing sectors in 1955. The gap for manufacturing productivity relative to the United States (US = 100) disappeared by 1980 and peaked at 103.8 in 1991. While it deteriorated somewhat afterward, the current gap is almost negligible. The motor vehicle industry, together with some other manufacturing industries of Japan, had a higher level of TFP than their US counterparts. As Japan's motor vehicle industry introduced Kaizen, TQM, and other related approaches much earlier and more intensively than the US motor vehicle industry (according to the MIT Commission on Industrial Productivity as discussed below), we could reasonably suppose that these approaches partly contributed to the impressive improvement of TFP level of the Japanese motor vehicle industry, particularly in the 1970s and 1980s. 
It should also be highlighted that the widespread dissemination of Kaizen, QCC, TQM, and related approaches has contributed significantly to the sustainable growth of Japan since the 1970s. The extensive dissemination of these approaches coincided with the era following the first oil crisis. In Japan, public awareness of environmental issues gradually grew during the 1960s as air and water pollution worsened with accelerated industrialization. The subsequent 1973 oil shock was a major turning point in that it forced Japanese companies and the general public to take measures for improving energy efficiency. As DBJ and JERI (2003) emphasize, "One of the significant impacts of Japanese TQC/TQM is often explained through descriptions of the development of the car industry after the oil crises in the 1970s. During this period, TQC was extended to activities for energy conservation and measures for resource maintenance. It greatly impacted on various industries and became more securely established as a valuable quality framework for Japanese industrial development" (46).

According to General Energy Statistics published by Japan's Agency for Natural Resources and Energy (2005), energy efficiency in Japan improved 37 percent between 1973 and 2003. In this period, total energy consumption in the industrial sector has stayed at the same level (around 180 million kiloliters of crude oil equivalent), while real GDP doubled (from 250 trillion to 520 trillion yen). Japan is one of the most energy-efficient countries in the world. Japanese $\mathrm{CO}_{2}$ emissions per GDP in 2005 were $0.24 \mathrm{~kg}$ of $\mathrm{CO}_{2} / \mathrm{US} \$$ compared with 0.43 in the EU and 0.53 in the United States (based on exchange rates in the year 2000; IEA 2007). The Energy Conservation Law, incentives offered by the government, company investments in energy-saving equipment and technologies, as well as their efforts through Kaizen-based QC activities, TQM, and related approaches are likely to have enabled these achievements.

\subsection{Experiences in the United States ${ }^{8}$}

In the United States, comparative studies between US and Japanese industries were made in the 1980s. One of the most well known is "Made in America, Regaining the Productive Edge," a report issued by the MIT Commission on Industrial Productivity (Dertouzos et al. 1989, xiii). The findings showed that one area in which US firms often lagged behind their overseas competitors was in exploiting the potential for continuous improvement in the quality and reliability of their products and processes 
(74). The report noted that "The cumulative effect of successive incremental improvements and modifications to established products and processes can be very large and may outpace efforts to achieve technological breakthroughs" (74). It further states that "In the long run, technological progress rests on a foundation of both incremental improvements and radical breakthroughs, and finding the right balance between them is a constant challenge. Lewis Branscomb (1987) has suggested that Japanese firms have been more effective in combining the two approaches" (74). ${ }^{9}$

Moreover, Womack et al. (1990), based on research from MIT's International Motor Vehicle Program (IMVP), concluded that:

The auto industries of North America and Europe were relying on techniques little changed from Henry Ford's mass production system and that these techniques were simply not competitive with a new set of ideas pioneered by the Japanese companies, methods for which we did not even have a name... [T] he Western companies didn't seem to be able to learn from their Japanese competitors. Instead, they were focusing their energies on erecting trade barriers and other competitive impediments, which we thought simply delayed dealing with the real issue... [W] feared that North America and Europe would seal themselves off from the Japanese threat and, in the process, reject the opportunity for the prosperity and more rewarding work that these new techniques offer. We felt that the most constructive step we could take to prevent this development from occurring would be to undertake a detailed study of the new Japanese techniques, which we subsequently named 'lean production', compared to the older Western mass-production techniques (3-4).

TQC/TQM and other management methods were gradually introduced into the US industries (DBJ and JERI 2003, 47). In this regard, Stiglitz and Greenwald $(2014,38)$ made an important observation in relation to the performance of the US manufacturing sector between the 1970 s and early 1980s on the one hand and the late 1980s and 1990s on the other:

Between these two periods, the annual rate of growth of U.S. manufacturing productivity rose by 2.0 per cent from 0.9 per cent to 2.9 per cent. The improvement coincided with a marked rise in U.S. real interest rates (normally associated with less investment in technology) and government deficits, a decline in U.S. research and development spending, and no detectable improvement in the performance of U.S. education (as measured by standardized tests). At the same time, it cannot be attributed to the availability 
of new technology. Such technology would have been equally available to other G7 economies. Over the period in question, the U.S. improvement in annual manufacturing productivity growth was 1.9 per cent higher than that of the other G7 countries. The improvement was thus a U.S., not a global, phenomenon. What seems to have changed in U.S. manufacturing was an intensified focus on improved operations management through the rigorous implementation of procedures like benchmarking, total quality management, and reengineering - in our language, an intensified focus on learning. America seemed to have learned how to learn (38).

Stiglitz and Greenwald $(2014,528)$ further noted that "interestingly, some of the learning involved learning from foreign firms, e.g., about quality circles and just in time production."

Regarding the car industry, the MIT's IMVP study referred to above found that the US companies improved car assembly productivity from 24 man hours/car unit to 20 between 1989 and 1993/1994, while Japanese companies improved from 16 man hours/car unit to 15 in the same period, confirming the catch-up process of the US car industry to its Japanese counterpart (Fujimoto 2003, 283).

These experiences confirm that the learning process has been closely related to approaches such as TQM, also seen in the United States. Together with experiences in Japan, this provides insights into effective approaches to create learning firms and learning societies, which are the main drivers of high-quality growth.

\subsection{Experiences in Singapore ${ }^{10}$}

Singapore was the first country in Southeast Asia to systematically introduce quality and productivity initiatives. According to former Prime Minister Lee Kuan Yew, "The shift to a knowledge-intensive industrial structure with strong international competitiveness is only possible through the human-resource development of 2.6 million people, the only resource Singapore has" (JPC 1990, 1). ${ }^{11}$ Lee's concern was how to organize and motivate Singapore's workforce to make best use of the modernization of plants and capacity building. In April 1981, the Committee on Productivity was set up by representatives of enterprises, worker organizations, government officials, and academics.

The committee reviewed the experiences of productivity movements in Japan, another country without natural resources. It then presented a 
report to the president of the National Productivity Board (NPB) of Singapore, which had been designated as the main body for promoting productivity development in Singapore. In June 1983, the Singapore Productivity Development Project (SPDP) was launched with the support of the Japanese government.

Some 15,000 Singaporean engineers, managers, and other professionals participated in the project. About 200 engineers, managers, and other professionals from Singapore took part in training courses in Japan, and more than 200 Japanese experts were dispatched to Singapore. In addition, more than 100 textbooks and other training materials were prepared specifically for the project. During the period of SPDP and beyond, labor productivity in manufacturing industries improved by an annual average rate of 5.7 percent (1981-1986), 3.0 percent (1986-1991), and 4.8 percent (1991-1996). In 1990, when SPDP ended, 90 percent of workers in the country were involved in productivity development activities, compared with 54 percent in 1986. In 2001, 13 percent of the total labor force was participating in quality control circles (QCC), in comparison with 0.4 percent in 1983, when SPDP started.

Experiences in Singapore have proven the effectiveness of Kaizen and related approaches for the transformation from unskilled labor-intensive industries to skilled labor-intensive or knowledge-intensive industries, strongly inspired by the country's leader Lee Kuan Yu. In this regard, JICA (2014) concludes that "the Kaizen Project laid the groundwork for Singapore's growth, contributing to upgrading the country's industrial structure" (4).

\subsection{Experiences in Thailand}

In 1995, Thailand's annual automobile exports were less than half a billion US dollars, well below exports from India and Malaysia. In 2008, exports approached 28 billion US dollars, making Thailand the largest automobile exporter in the ASEAN region, and by 2012, Thailand was the seventh largest exporter in the world. It was estimated in 2010 that there were about 690 first-tier parts makers, 30 percent of them Thaimajority joint venture companies, with 23 percent of them pure Thai companies. There were also 1700 second- and third-tier parts makers, most of them locally owned small and medium enterprises (SMEs), supporting the automobile industry in Thailand (Natsuda and Thoburn $2011,8)$. At present, the automobile industry is the principal engine for 
growth in Thailand's economy. "The Detroit of Asia" envisaged once by the Thai government is now a reality. As Athukorala and Kohpaiboon (2011) point out, "the automobile industry has been the target of industrial development in many countries as a driver of growth-a source of employment, technological expertise, and a stimulus to other sectors through backward linkages... But only a handful of developing countries have managed to develop an internationally competitive automobile industry." Thus, Thailand successfully achieved a transformation of its industrial structure.

In this process, "Japanese assemblers played a crucial role in the development of automobile production and supporting industries" (Techakanont 2015, 204). For example, the Toyota Production System (TPS) has been introduced:

Toyota facilitated interfirm knowledge-sharing through supplier associations, knowledge-transfer consultants and small-group learning teams (Dyer and Nobeoka 2000). Toyota created the Toyota Cooperation Club (TCC) and established a training center in 1982, when they had around thirty-five suppliers. This number increased to more than 160 members (as first-tier suppliers) in 2014. The TCC organized activities to increase capabilities in the TPS. It shared explicit and tacit knowledge on its System through company visits by Toyota's trained consultants. As a member, suppliers received free consulting services. Experts at Toyota Thailand also provided TPS training to parts manufacturers in other ASEAN countries. Another initiative was the coordination of learning activities in small groups, intended to encourage suppliers to learn and share specific tacit knowledge with each other (Techakanont 2015, 205).

One of the largest public-private supplier development efforts, apart from private initiatives such as Toyota's, was the Thailand Automotive Human Resource Development Project (AHRDP) for first-tier and second-tier suppliers, which ran from 2006 to 2010. It was implemented with the support of JICA and four Japanese companies, including Toyota, which provided TPS training. In total, 233 SMEs and 7151 workers participated in AHRDP. According to Techakanont (2015), a poll of 200 case studies conducted by the Thai Automotive Institute (TAI) on the results of the AHRDP revealed that, on average, suppliers were able to improve productivity by 30 percent to 50 percent, reduce work-in-process inventory by 25 percent to 75 percent, and free up 30 percent to 50 percent of factory space (206-207). 
Beginning in 2012, the Automotive Human Resource Development Institute Project (AHRDIP) conducted a five-year program with the aim of providing a higher level of technological content. The specific goals of the AHRDIP were, among other aims, to instruct 1000 trainers who would then train 255,000 personnel in manufacturing, to teach 200 trainers and 30,000 personnel in testing, and to teach 100 trainers and train 15,000 personnel in R\&D (Techakanont 2015, 208).

\subsection{Experiences in Tanzania and Other African Countries}

Tanzania became a pioneer in introducing Kaizen and total quality management (TQM) in hospitals. ${ }^{12}$ Building on the inspiration gained from Sri Lankan best practice and witnessing the visible changes in the first pilots at Mbeya Referral Hospital (MRH), the Ministry of Health and Social Welfare (MoHSW) officially adopted the 5S-Kaizen-TQM approach to provide the core of the national quality improvement program as part of the National Health Sector Strategy. With many specific initiatives of MoHSW, this approach has started to take root in a number of hospitals in Tanzania.

This approach has, first of all, been officially designated the foundation of all quality improvement (QI) approaches in Tanzania. As of September 2012, some fifty-six hospitals-including all national, specialized and regional referral hospitals as well as a number of municipal and district hospitals - have established quality improvement teams (QITs) and have implemented 5S. Of these hospitals, thirteen have moved to the second step of Kaizen: evidence-based participatory problem-solving actions for service quality improvement. Through the cascade approach, well over 5000 health workers have been trained in 5 S. Some of the achievements through Kaizen include reductions of overstocked inventory, reductions in waiting time for patient consultations (down to one-third from forty-six minutes to fifteen minutes), and increases in hospital income through better processing of insurance claims (Honda 2012, 117-119; Takizawa 2013). This experience demonstrates effects of the Kaizen approach in improving quality and productivity of health care services.

Over five years of continuous efforts have made Tanzania a center of excellence in quality improvement of hospital care through application of 5S-Kaizen-TQM in Africa. JICA is working in partnership with Sri Lanka in applying this approach to improve hospital management in over fifteen countries in Africa (Takizawa 2013, 259). Several countries have main- 
streamed or are in process of mainstreaming the approach in their strategies and framework of quality assurance for health services. As such, Tanzania emerged as a pivotal country in this approach by providing an example for other African countries to emulate (Honda 2012, 119-120).

\section{Concluding Remarks}

The case studies of experiences presented here illustrate the application of Kaizen in a variety of contexts with significant impact. As Kaizen and related approaches do not demand large investments, they enabled the Japanese manufacturing industry to improve productivity and competitiveness during the post-war period, when the availability of funds for investment was severely limited. During the post-1973 oil crisis era, a time when Japanese companies were seriously affected by energy price hikes, Kaizen and related approaches were introduced very widely-not only into manufacturing industries but also into finance, insurance, construction, health care, and other sectors. In the United States, improved operational management systems, including TQM, were widely introduced to manufacturing industries.

In Singapore and Thailand, where Kaizen was introduced-at least into some of the sectors that are leading their economic growth-the increase in productivity was crucial to the transformation of their industrial structure. In Singapore, Kaizen and related approaches contributed to the transformation from unskilled labor-intensive industries to skilled labor-intensive or knowledge-intensive industries. In Thailand, scaling-up of supporting industries for automobile industry was facilitated by the development of small and medium parts industries that benefited from, among other things, Kaizen and related approaches such as TPS. The competitive automobile industry contributed to the transformation of the industrial structure of the country.

Experiences in the hospitals of Tanzania and other African countries clearly demonstrate the possibility of introducing Kaizen and related approaches to sectors other than the manufacturing industry, as has occurred in Japan and other Asian countries.

These diverse experiences provide evidence of some other important features of Kaizen and related approaches. For example, they are inexpensive without the need for much investment and are easily applied. The sizable dissemination of QCC in the 1970s and 1980s in Japan was possible because of these features. 
In short, Kaizen, TQM, and related approaches were able to contribute to growth-and in particular to high-quality growth-by increasing productivity through learning. It also enabled transformation through enhancing learning capacity, especially learning how to learn ("learning to learn" in terms of Stiglitz and Greenwald 2014), the essential endowment for industrial transformation. These approaches are intrinsically inclusive, because they are approaches in which participation by all and their learning are essential. They are also able to contribute to sustainable growth because they reduce use of materials and improve energy efficiency by eradicating muda. Such approaches improve security and safety for workers as well through elimination of muri, mura, and so forth. Therefore, Kaizen, TQM, and related approaches can contribute to the achievement of Goal 8 of SDGs by facilitating directly and indirectly sustained, inclusive, and sustainable economic growth, full and productive employment, and decent work. However, it should be recognized that there are challenges to fully implementing these approaches in the many diverse contexts of developing countries and that further in-depth studies are needed to address these challenges effectively.

\section{Notes}

1. This chapter draws partly on the author's previous works such as Hosono $(2009,2015 a, b, 2017)$.

2. For a literature review and discussion on the quality of growth, see Haddad et al. (2015) and Hosono (2015a).

3. "The APEC (Asia Pacific Economic Cooperation) Leaders' Growth Strategy" was agreed on November 14, 2010. It is referred to as the "APEC Growth Strategy."

4. Dr. Kaoru Ishikawa, ex-Rector of the Musashi Institute of Technology (recently renamed Tokyo City University), is considered to be the "founder of quality control in Japan," as well as the father of the QC circle, as a result of the important theoretical and practical contributions he made. His book, Introduction to Quality Control, first published in 1954 (Ishikawa 1954), is one of the most widely read books in Japan in this field. The third edition (1989) was translated into English and published in 1990 (Ishikawa 1990). There are also a large number of well-known engineers and managers who have promoted quality activities in many Japanese companies. One of the most prominent is Mr. Taiichi Ohno, ex-Vice President of Toyota Motor Company. $\mathrm{He}$ is one of those who consolidated the Toyota 
Production System (TPS). Another prominent Japanese engineer who contributed substantially to quality activities is Dr. Shigeo Shingo, a consultant for Toyota and Panasonic, among others. In recognition of his work, Utah State University created "The Shingo Prize." Mr. Masaaki Imai, who once worked for the Japan Productivity Center in Washington DC, founded the Kaizen Institute Consulting Group in 1986 and, in the same year, wrote Kaizen: The Key to Japan's Competitive Success.

5. For example, Toyota's TQM comprises the integration of three main points that must be present in order for the company to succeed: focus on customers, continual improvement, and participation by all employees (DBJ and JERI 2003, 3, 7).

6. This explanation of the relationship between CWQC, TQC and TQM is based on DBJ and JERI $(2003,2)$.

7. According to Liker (2004), "The Toyota Way" can be briefly summarized through the two pillars that support it: "Continuous Improvement" and "Respect for People." Continuous improvement, often called Kaizen, defines Toyota's basic approach to doing business: "challenge everything." Liker states: "More important than the actual improvements that individuals contribute, the true value of continuous improvement is in creating an atmosphere of continuous learning and an environment that not only accepts but actually embraces change. Such an environment can only be created where there is respect for people-hence the second pillar of the Toyota Way. Toyota demonstrates this respect by providing employment security and seeking to engage team members through active participation in improving their jobs" (xi-xii; italics in original).

8. This part heavily draws from Hosono (2017).

9. In this regard, Imai (1986) compares Kaizen and "innovation." These concepts correspond, respectively, to "incremental improvement" and "breakthrough" in terms of Dertouzos et al. (1989). According to Imai, Kaizen is of long-term and long-lasting effect, with small steps, with the involvement of everybody, based on conventional know-how and state-ofthe-art practices that require little investment. "Innovation," on the other hand, is of short-term but dynamic effect, with big steps, with involvement of a selected few "champions," based on technological breakthroughs, new inventions and new theories, and requires large investments (Imai 1986, 25).

10. This part draws heavily from Hosono (2015b).

11. Comments made by the Prime Minister during his visit to Mr. Kohei Goshi, honorary President of the Japan Productivity Center (JPC) in June 1981 (JPC 1990, 1).

12. This paragraph draws mainly from Honda (2012). 


\section{REFERENCES}

Agency for Natural Resources and Energy. 2005. General Energy Statistics. Tokyo: Agency for Natural Resources and Energy.

Asian Development Bank (ADB). 2013. Key Indicators for Asia and the Pacific: Asia's Economic Transformation: Where to, How, and How Fast? Manila: ADB.

Asian Productivity Organization (APO). 2015. Handbook on Productivity. Tokyo: APO.

Athukorala, Prema-Chandra, and Archanun Kohpaiboon. 2011. Thailand in Global Automobile Networks. Paper Submitted to Study for the International Trade Center, Geneva.

Branscomb, Lewis. 1987. Towards a National Policy on Research and Development. Conference Sponsored by the Council on Research and Technology (CORETECH) and the Conference Board, MIT, October 8 (Cited by Dertouzos et al. 1989.).

Dertouzos, Michael, Richard Lester, and Robert Solow. 1989. Made in America: Regaining the Productive Edge. Cambridge, MA: MIT Press.

Development Bank of Japan (DBJ) and Japan Economic Research Institute (JERI). 2003. Handbook for TQM and QCC. Washington, DC: Inter-American Development Bank (IDB).

Dyer, Jeffrey H., and Kentaro Nobeoka. 2000. Creating and Managing a HighPerformance Knowledge-Sharing Network: The Toyota Case. Strategy Management Journal 21 (3): 345-367.

Energy Conservation Center Thailand (ECCT) and Energy Conservation Center Japan (ECCJ). 2005. The Energy Management Handbook. Bangkok and Tokyo: ECCT and ECCJ.

European Center for Development Policy Management (ECDPM). 2008. Capacity, Change, and Performance: Study Report. Discussion Paper 59B. April. Maastricht, Holland: ECDPM.

Fujimoto, Takahiro. 2003. Nouryoku Kouchiku Kyouso: Nihon no Jidousha Sangyou wa Naze Tsuyoinoka? [Competition of Capacity Building: Why is the Japanese Car Industry Strong?]. Tokyo: Chuo Koron Sha.

Government of Japan, Cabinet Office. 2015. Development Cooperation Charter. Tokyo: Cabinet Office.

Haddad, Lawrence, Hiroshi Kato, and Nicolas Meisel, eds. 2015. Growth is Dead, Long Live Growth: The Quality of Economic Growth and Why it Matters. Tokyo: JICA Research Institute.

Honda, Shunichiro. 2012. Inspired by Sri Lankan Practice: Scaling-up 5S-KAIZEN-TQM for Improving African Hospital Service. In Scaling Up South-South and Triangular Cooperation, ed. Hiroshi Kato, 107-127. Tokyo: JICA Research Institute. 
Hosono, Akio. 2009. Kaizen: Quality, Productivity and Beyond. In Introducing Kaizen in Africa, ed. GRIPS Development Forum, 23-37. Tokyo: National Graduate Institute for Policy Studies (GRIPS).

- 2015a. Industrial Transformation and Quality of Growth. In Growth is Dead, Long Live Growth: The Quality of Economic Growth and Why it Matters, ed. Lawrence Haddad, Hiroshi Kato, and Nicolas Meisel, 267-300. Tokyo: JICA Research Institute.

- 2015b. Industrial Strategy and Economic Transformation: Lessons from Five Outstanding Cases. In Industrial Policy and Economic Transformation in Africa, ed. Akbar Noman and Joseph Stiglitz, 53-101. New York: Columbia University Press.

- 2017. Industrial Strategies Toward a Learning Society for Quality Growth. In Efficiency, Finance, and Variety of Industrial Policy: Guiding Resources, Learning, and Technology for Sustained Growth, ed. Akbar Noman and Joseph Stiglitz, 306-352. New York: Columbia University Press.

Hosono, Akio, Shunichiro Honda, Mine Sato, and Mai Ono. 2011. Inside the Black Box of Capacity Development. In Catalyzing Development: A New Vision for Aid, ed. Homi Kharas, Koji Makino, and Woojin Jung, 179-201. Washington DC: Brookings Institution.

Imai, Masaaki. 1986. Kaizen: The Key to Japan's Competitive Success. New York: McGraw-Hill.

International Energy Agency (IEA). 2007. CO2 Emissions from Fuel Combustion 1971-2005. Paris: IEA.

Ishikawa, Kaoru. 1954. Hinshitsu Kanri Nyumon [Introduction to Quality Control]. Tokyo: JUSE Press.

- 1990. Introduction to Quality Control. Tokyo: 3A Corporation.

Japan Productivity Center (JPC). 1990. Singapore Productivity Improvement Project. Tokyo: JPC.

JICA. 2006. Capacity Development: What Is CD? How JICA Understands CD, and How-to Concepts for Improving JICA Projects. Tokyo: JICA.

- 2008. Capacity Assessment Handbook: Managing Programs and Projects toward Capacity Development. Tokyo: JICA.

- 2014. The Kaizen Project: Laying the Groundwork for Singapore's Growth. JICA's World, January 2014. Tokyo: JICA.

- 2016. Kaizen: Japan's Approach Towards Improved Quality and Productivity. Tokyo: JICA.

Jorgenson, Dale W., Koji Nomura, and Jon D. Samuels. 2015. A Half Century of Trans-Pacific Competition: Price Level Indices and Productivity Gap for Japanese and U.S. Industries, 1955-2012. RIETI Discussion Paper Series 15-E-054. Tokyo: Research Institute of Economy, Trade and Industry (RIETI). 
Kikuchi, Tsuyoshi. 2009. JICA-Supported Project for Quality and Productivity Improvement in Tunisia. In Introducing Kaizen in Africa, ed. GRIPS Development Forum, 39-54. Tokyo: GRIPS.

Liker, Jeffrey K. 2004. The Toyota Way. New York: McGraw Hill.

Lin, Justin Yifu. 2012. New Structural Economics: A Framework of Rethinking Development and Policy. Washington, DC: World Bank.

Natsuda, Kaoru, and John Thoburn. 2011. Industrial Policy and the Development of the Automotive Industry in Thailand. Working Paper No. 11(5). Ritsumeikan Center for Asia Pacific Studies (RCAPS).

Noman, Akbar, and Joseph Stiglitz. 2012. "Strategies for African Development." In Good Growth and Governance for Africa: Rethinking Development Strategies, edited by Akbar Noman, Kwesi Botchwey, Howard Stein, and Joseph Stiglitz, 3-47. New York: Oxford University Press.

- 2017. Learning, Industrial, and Technology Policies: An Overview. In Efficiency, Finance, and Varieties of Industrial Policy: Guiding Resources, Learning, and Technology for Sustained Growth, ed. Akbar Noman and Joseph E. Stiglitz, 1-20. New York: Columbia University Press.

Stiglitz, Joseph, and Bruce Greenwald. 2014. Creating a Learning Society: A New Approach to Growth, Development, and Social Progress. New York: Columbia University Press.

Takizawa, Ikuo. 2013. Toward Universal Health Coverage in Africa-Achieving MDGs with Equity, and Beyond. In For Inclusive and Dynamic Development in Sub-Saharan Africa, ed. JICA Research Institute, 247-266. Tokyo: JICA Research Institute.

Techakanont, Kriengkrai. 2015. Supplier Development Programs in the Automotive Industry in Asia. In Rising Concentration in Asia-Latin American Value Chains: Can Small Firms Turn the Tide? ed. Osvaldo Rosales, Keiji Inoue, and Nanno Mulder, 183-214. Santiago: UN-ECLAC.

United Nations Development Program (UNDP). 1998. Capacity Assessment and Development in a Systems and Strategic Management Context. MDGB Technical Advisory Paper 3. New York: UNDP.

United Nations General Assembly (UNGA). 2015. The 2030 Agenda for Sustainable Development. New York: United Nations.

Womack, James, and Daniel Jones. 1996. Lean Thinking: Banish Waste and Create Wealth in Your Corporation. New York: Free Press.

Womack, James, Daniel Jones, and Daniel Roos. 1990. The Machine that Changed the World: The Story of Lean Production. New York: Macmillan.

World Bank. 2015. World Development Report 2015: Mind, Society, and Behavior. Washington, DC: World Bank. 
Open Access This chapter is licensed under the terms of the Creative Commons Attribution 4.0 International License (http://creativecommons.org/licenses/ by $/ 4.0 /$ ), which permits use, sharing, adaptation, distribution and reproduction in any medium or format, as long as you give appropriate credit to the original author(s) and the source, provide a link to the Creative Commons licence and indicate if changes were made.

The images or other third party material in this chapter are included in the chapter's Creative Commons licence, unless indicated otherwise in a credit line to the material. If material is not included in the chapter's Creative Commons licence and your intended use is not permitted by statutory regulation or exceeds the permitted use, you will need to obtain permission directly from the copyright holder.

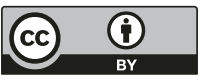

